JP LPPM UNRI, ISSN: 2086-4779, e-ISSN: 2715-8209

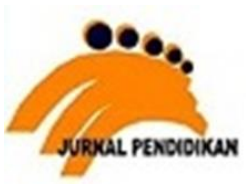

Jurnal Pendidikan

https://jp.ejournal.unri.ac.id/index.php/JP/index

\title{
PEMBELAJARAN SEJARAH DALAM PERSPEKTIF PEDAGOGI KRITIS
}

\author{
Piki Setri Pernantah \\ Program Studi Pendidikan Sejarah FKIP Universitas Riau \\ piki.setri@lecturer.unri.ac.id
}

\begin{abstract}
This article is a theoretical study using the method of literacy study. It aims to discuss and study historical learning in a new perspective. Learning of history should be oriented to provide historical knowledge and introduce the noble values of the nation. Because, those two things will not have meaning for the lives of students if they do not understand the meaning of every historical event that they have learned. Efforts to realize meaningful historical learning, related to students' actions for reflective thinking. One thing that cannot be separated from the study of critical pedagogy is reflective thinking. Applying critical pedagogy in learning history, which means emphasizing critical theory as an analytical tool for reading various historical realities in learning. It is expected that students will be able to interact with each other and study various historical realities so that they can reflect on themselves and think critically about these realities. Discussing the learning of history in the concept of critical pedagogy is a new approach that seeks to help students in the process of historical learning. So that they can question and criticize every material in historical learning so that it gives birth to criticalreflective thinking that makes students able to learn and interpret every historical fact and historical learning material in school.
\end{abstract}

Keywords: learning of history, critical pedagogy

Abstrak:. Artikel ini bersifat kajian teoritis dengan menggunakan metode literacy study. Bertujuan untuk mendiskusikan dan mengkaji mengenai pembelajaran sejarah dalam perspektif baru. Pembelajaran sejarah hendaklah berorientasi untuk memberikan pengetahuan sejarah dan memperkenal nilai-nilai luhur bangsa. Sebab, kedua hal itu tidak akan memiliki arti bagi kehidupan peserta didik apabila mereka tidak memahami makna dari setiap peristiwa sejarah yang dipelajarinya. Upaya mewujudkan pembelajaran sejarah yang bermakna, tidak terlepas dari tindakan peserta didik untuk berpikir reflektif. Suatu hal yang tidak dapat dipisahkan dari kajian pedagogi kritis adalah pemikiran reflektif. Menerapkan pedagogi kritis dalam pembelajaran sejarah artinya menekankan teori kritis sebagai alat analisis untuk membaca berbagai fenomena sejarah dalam pembelajaran. Diharapkan peserta didik mampu untuk saling berinteraksi dan mengkaji berbagai fenomena sejarah agar mampu merefleksi diri dan berpikir kritis terhadap berbagai fenomena tersebut. Mengkaji pembelajaran sejarah dalam konsep pedagogi kritis merupakan suatu pendekatan baru yang berupaya membantu peserta didik dalam proses pembelajaran sejarah. Agar mereka dapat 
mempertanyakan dan mengkritisi setiap materi yang ada dalam pembelajaran sejarah sehingga melahirkan suatu pemikiran kritis-reflektif yang membuat peserta didik mampu belajar dan memaknai setiap fakta sejarah dan materi pembelajaran sejarah di sekolah.

Kata kunci: pembelajaran sejarah, pedagogi kritis

\section{PENDAHULUAN}

Pembelajaran sejarah pada hakekatnya merupakan mata pelajaran yang termasuk ke dalam rumpun ilmu-ilmu sosial yang bersumber dari kehidupan sosial masyarakat dan diseleksi dengan menggunakan bantuan teori-teori atau konsep-konsep dari ilmu sosial lainnya. Sayono (2006) menjelaskan bahwa mata pelajaran sejarah di Sekolah Menengah Atas mengandung dua misi yaitu: Pertama, untuk pendidikan intelektual. Kedua, untuk pendidikan nilai, pendidikan kemanusian, pendidikan pembinaan moralitas, jati diri, nasionalisme, dan identitas bangsa. Senada yang diungkapkan Agung \& Wahyuni (2013), mata pelajaran sejarah adalah mata pelajaran yang memanamkan pengetahuan, sikap, dan nilai mengenai proses perubahan dan perkembangan masyarakat Indonesia dan dunia dari masa lampau hingga masa kini.

Pembelajaran sejarah di sekolah menengah di Indonesia pada dasarnya bersandar pada prinsip "filosofis-ideologis", sejalan dengan tujuan pendidikan nasional, yaitu untuk membangun semangat kebangsaan, memupuk jiwa nasionalisme dan keberagaman serta rasa bangga para peserta didik terhadap hasil karya nenek moyang di masa lalu, sehingga pembelajaran sejarah diharapkan mampu menjadi wahana pendidikan, yang memungkinkan para peserta didik memainkan peran yang bertanggung jawab dalam masyarakat. Dengan peranan penting yang demikian, maka pembelajaran sejarah saat ini mulai memiliki posisi penting dan menjadi pusat perhatian bangsa. Hal itu dibuktikan dengan mata pelajaran sejarah menjadi salah satu mata pelajaran wajib di sekolah menengah (Pernantah, 2016).

Pembelajaran sejarah juga berperan penting dalam menyiapkan warga negara muda untuk menghadapi tantangan dan perubahan zaman yang sesuai dengan jiwa zamannya masing-masing. Pembelajaran sejarah perlu dikonstruksi secara humanis, dialogis, kritis, dan mengedepankan sikap yang baik untuk membangun kemampuan berpikir kritis peserta didik dalam kehidupan masyarakat Indonesia demokratis. Namun, pada kenyataannya yang terjadi di sekolah hari ini masih banyak dilihat guru dalam mengajarkan materi sejarah yang jauh dari realitas kehidupan 
peserta didik dan memberikan stimulus agar peserta didik dapat berpikir lebih kritis. Para peserta didik masih dihadapkan pada serangkaian fakta-fakta sejarah dan bersifat hapalan. Sehingga hal tersebut menimbulkan perspektif lain terhadap pembelajaran sejarah sebagai pembelajaran yang terkesan kaku dan monoton serta dianggap membosankan. Materi masih terkesan untuk mengejar peningkatan di ranah kognitif saja sedangkan di ranah afektif dan psikomotor belum terlalu mendapat perhatian lebih oleh para guru. Seharusnya pembelajaran sejarah mampu berkontribusi dalam memberikan sumbangsih untuk pembentukan kharakter peserta didik dan kemampuan berpikir kritisnnya, ternyata hal itu belum mampu terwujud secara signifikan. Pembelajaran sejarah masih terasa kering dan seolah-olah sumber sejarah bukanlah kenyataan yang bisa dirasakan atau diamati dari lingkungan sekitar. Hal ini terjadi dikarenakan materi yang diajarkan terlalu tertumpu pada uraian buku teks.

Berbagai fenomena di atas menunjukkan bahwa saat ini permasalahan pembelajaran sejarah begitu cukup kompleks. Hal ini didasarkan oleh kasus-kasus yang terjadi di lapangan yang terkait dengan pelaksanaan pembelajaran sejarah di sekolah. Guna menghadapi tantangan tersebut, maka menempatkan pembelajaran sebagai topik penting untuk dilakukan inovasi dalam pembelajaran dengan pendekatan baru, dan mendesak para guru sejarah untuk terus belajar dan memperbaruhi pembelajaran sejarah ke arah yang lebih baik. Hal ini tidak lain adalah untuk menghadapi tantangan tersebut menuju pembelajaran sejarah yang sesuai dengan tujuan kompetensi dalam kurikulum 2013.

Kurikulum pembelajaran sejarah juga diharapkan dapat membantu peserta didik membangun landasan untuk memahami kenyataan masyarakat dengan belajar dari setiap peristiwa masa lalu. Kecintaan terhadap bangsa bukanlah merupakan doktrin ideologi yang bersifat pasif dan dogmatis, tetapi bersifat dinamis. Artinya, senantiasa menghadapi perubahan yang sedang akan terjadi. Hal ini perlu ditanamkan dengan harapan ketahanan diri sebagai warga negara dapat terpelihara terutama ketika menghadapi gelombang perubahan yang menembus berbagai sendi kehidupan peserta didik jangan sampai tercerabut rasa kebangsaannya. Maka dari itu, peran pembelajaran sejarah sangat berkontribusi dalam meningkatkan rasa cinta atas bangsanya sendiri.

Pada konteks inilah, penting kiranya menelaah diskursus pendidikan kritis melalui critical pedagogy dan rasionalitas dalam kajian pembelajaran sejarah di sekolah untuk mewujudkan 
peserta didik yang kritis dan berpikir reflektif sehingga dapat merespon perkembangan dan tuntutan zaman untuk menjadikan diri sebagai warga negara yang baik. Hal yang tak kalah penting adalah bagaimana peran guru dalam mewujudkan kebijakan pembelajaran yang berorientasi pada pembelajaran dengan pendekatan saintifik, kreatif, dan bermakna.

Ulasan di atas sangat menarik untuk dikaji lebih mendalam dalam pembelajaran sejarah sehingga dapat diperoleh hasil kajian yang komprehensif tentang diskursus pendidikan kritis (critical pedagogy) dalam kajian pembelajaran sejarah untuk dapat mewujudkan peserta didik yang memiliki kemampuan berpikir kritis dan reflektif. Oleh karena itu, pada pembahasan artikel ini akan memfokuskan kajian pada pembelajaran sejarah dalam kajian pedagogi kritis. Dimana pedagodi kritis berupaya untuk membantu peserta didik dalam proses pembelajaran sejarah yang mempertanyakan dan mengkritisi setiap materi yang ada dalam pendidikan sejarah sehingga akan melahirkan suatu pemikiran reflektif (reflektive thinking) yang membuat peserta didik mampu belajar dan memaknai setiap peristiwa sejarah dan materi yang ada dalam pendidikan sejarah.

\section{METODE PENELITIAN}

Tulisan ini bersifat kajian teoritis atau konseptual dengan menggunakan metode deskriptifkualitatif melalui pendekatan studi kepustakaan atau literacy study. Penelitian ini bertujuan untuk mendiskusikan mengenai pembelajaran sejarah dari perspektif baru dan kritis. Data bersumber dari berbagai jurnal, buku, makalah, dan artikel ilmiah lainnya yang dikumpulkan melalui teknik dokumentasi, identifikasi konsep dan wacana dari berbagai buku, jurnal, makalah, artikel online, majalah, surat kabar, dan sumber bacaan lain yang relevan dan berhubungan dengan diskursus pedagogi kritis dalam kajian pembelajaran sejarah. Sementara, teknik analisis data yang digunakan dalam artikel ini mengacu pada teknik analisis isi dengan mengorganisasikan dan mengkategorikan data untuk menemukan hasil penelitian yang akan menjadi kesimpulan dalam tulisan ini

\section{HASIL DAN PEMBAHASAN}

Menurut Sadulloh (2011) pedagogik merupakan ilmu yang membahas pendidikan, yaitu ilmu yang berfokus pada pendidikan anak. Jadi, pedagogik mencoba menjelaskan tentang seluk-beluk pendidikan anak dan merupakan teori pendidikan anak. Daryanto dan Tantrial (2012) juga menambahkan pendapat dari Uyoh, bahwa pada pedagogi, pengajar merupakan tokoh utama yang berperan penting dalam pembelajaran. Sebab seorang pengajar dalam proses pembelajaran 
tersebut akan mengatur segala proses mengajar, mulai dari perencanaan, pemilihan materi dan penentuan metode pembelajaran. Dengan proses belajar pedagogi, peserta didik akan tergantung kepada guru sebagai pengajar dan komunikasi dalam proses pembelajaran akan bersifat satu arah atau direktif serta pengalaman pengajar merupakan satu-satunya sumber bagi anak didik.

Istilah 'Pedagogi' secara literatur juga dapat dipahami sebagai sebuah seni atau pengetahuan untuk mengajar anak-anak (the art or science of teaching children). Kata 'pedagogik' berasal dari bahasa Yunani 'Paidagogos' yang terdiri dari kata "paidos" (child) dan "agogos" (lead). Maksudnya adalah, memimpin anak dalam belajara. Dari berbagai referensi dapat dijelaskan bahwa secara historis dalam sejarah Yunani Kuno, fenomena ini dialami leh para budak yang mengawasi dan memberikan instruksi anak majikannya. Budak ini mendampingi dan mengajarkan anak majikanya hingga setiap hari mengantarkan ke sekolah. Budak ini juga membawa peralatan anak majikannya itu seperti alat musik dan alat pelajaran lainnya. Istilah 'pedagogi' juga dalam bahasa latin berasal dari kata: anak-instruksi, sedang digunakan modern dalam bahasa Inggris untuk merujuk pada konteks seluruh pengajaran, pembelajaran, dan operasi yang sebenarnya yang terlibat di dalamnya, meskipun kedua kata memiliki kira-kira makna aslinya yang sama. Dalam bahasa Inggris, istilah pedagogi digunakan untuk merujuk kepada teori insruktif; guru peserta pelatihan mempelajari subjek mereka dan juga pedagogi yang sesuai untuk mengajar subjek (Hidayat, 2013).

Selain konsep pedagogi juga terdapat konsep andragogi. Konsep andragogi lebih membahas orang dewasa belajar dan mengajar. la disebut andragogi sebagai seni dan ilmu mengajar orang dewasa. Oleh karena itu, istilah pedagogi kemudian dipahami secara lebih luas sebagai seni pengajaran secara umum. Dalam perkembanganya pedagogi sering dimaknai sebagai pendidikan/ilmu mendidik (ilmu mendidik anak yang belum dewasa), sedangkan mendidik/ilmu mendidik orang dewasa disebut andragogi. Meskipun demikian penggunaan istilah pedagogi sering dimaksudkan sebagai pendidikan dalam arti umum/luas tanpa membedakan tingkatan usia kematangan seseorang. Hidayat (2013) menambahkan bahwa beberapa kalangan membedakan istilah 'pedagogi' dalam 'andragogi'. Istilah andragogi ini awalnya dugunakan oleh Alexander Kapp, seorang pendidik dari Jerman, di tahun 1833. Istilah ini dikembangkan menjadi teori pendidikan orang dewasa (adult education). Andragogi mempelajari sifat fisik, psikis dan karakter orang dewasa.

Gagasan pedagogi kritis sangat dipengaruhi oleh pemikir sekaligus praktisi pendidikan dari Brazil yaitu Paulo Freire (1921-1997). Pedagogi kritis sangat prihatin dengan konfigurasi relasi antara guru dan murid dengan menggunakan dialog yang bermakna. Konsep pedagogi kritis dilahirkan dari refleksi dan pengalaman hidup Paulo Freire. Freire dilahirkan dalam keluarga kelas 
menengah di recife, Brazil. Namun, ia mengalami langsung kemiskinan dan kelaparan pada masa depresi besar 1929, suatu pengalaman yang membentuk keprihatinannya terhadap kaum miskin dan ikut membangun pandangan dunia pendidikannya yang khas. Pengalaman ini akan membentuk keprihatinanya terhadap kaum miskin dan akan membantu untuk membangun pemahaman pendidikan berdasarkan pengalamanya. Freire menyatakan bahwa kemiskinan dan kelaparan sangat mempengaruhi keputusan untuk belajar (Hidayat, 2013). Paulo Freire menerbitkan buku yang berjudul pedagogy of the oppressed, yang diterbitkan dalam bahasa Spanyol dan Inggris pada 1970. Buku Freire tersebut mengukuhkan gagasan agresifnya tentang pedagogi kritis. Gagasan Freire itu kemudian mengispirasi berbagai kalangan untuk melakukan perubahan sosial pada ranah pendidikan menuju pendidikan yang lebih humanis dan demokratis. Pedagogi kritis didefinisikan sebagai teori pendidikan dan praktik pembelajaran yang di desain untuk membangun kesadaran kritis mengenai kondisi sosial yang menindas. Pedagogi kritis merupakan pendekatan pembelajaran yang berupaya membantu murid mempertanyakan dan menentang dominasi serta keyakinan dan praktik-praktik yang mendominasi.

Pedagogi kritis pada dasarnya juga dapat dipahami dalam dua makna. Pertama, pedagogi kritis sebagai paradigma berpikir. Dalam hal ini pedagogi kritis dibangun atas dasar critical thinking untuk selalu mempertanyakan dan mengkritisi pendidikan itu sendiri dalam hal-hal fundamental tentang pendidikan baik dalam tatanan filosofis, teori, sistem kebijakan maupun implementasi. Kedua, pedagogi kritis sebagai gerakan sosial. Tujuan akhir pedagogi kritis adalah melahirkan praksis pendidikan yang egaliter, humanis, demokratis berbasis critical thinking dikalangan peserta didiknya (Hidayat 2013).

Pedagogi kritis sesungguhnya merupakan konsep yang tidak sulit. Namun ketika konsep ini diterapkan di bidang pendidikan sejarah akan menjadi kompleks. Di dalam teori pendidikan, menurut MacDonald (2002) pedagogi secara tipikal merujuk pada "seni" atau "ilmu" mengajar. Dalam konteks pedagogi kritis pedagogi tidak semata berhenti pada hal-hal teknis pengajaran seperti perencanaan instruksional, pembelajaran dan kurikulum, tetapi lebih ke arah pengertian bahwa pedagogi di konstruksi secara sosial dan merupakan proses dan praktek budaya tertentu.

Pedagogi kritis dipahami sebagai teori dan praktek pendidikan yang di desain untuk membangun critical awareness peserta didik. Pedagogi kritis berpandangan bahwa pendidikan harus dikembalikan pada hakikatnya, mengembangkan potensi kemanusian peserta didik. Sehingga pendidikan tidak dapat diselenggarakan hanya untuk memenuhi kepala peserta didik dengan pengetahuan tanpa makna. Dalam tataran praktek pembelajaran, Uhar Suharsaputra mengutarakan empat hal yang menjadi konsep penting dan menjadi bagian dari pedagogi kritis 
yakni constructivisme, banking concept of education, problem posing education, dan dialogical method. Pembelajaran harus menempatkan peserta didik sebagai subjek (student-center) sehingga mereka tidak hanya menerima konsep-konsep yang diberikan guru di dalam proses pembelajaran. Pembelajaran harus menjadikan peserta didik turut serta aktif dalam memperoleh pengetahuannya dengan diberikan berbagai strategi dan metode yang menghadapkan peserta didik dengan masalah yang dialami atau ditemui di masyarakat. Selanjutnya, pembelajaran yang dalam perspektif pedagogi kritis harus adanya dialog sehingga terjadinya komunikasi dua arah antara guru dan peserta didik. Pembelajaran akan menjadi efektif dan benar karena segala hal yang disampaikan oleh guru akan mampu diserap secara baik oleh peserta didik di dalam proses pembelajaran.

Suatu hal yang juga tidak bisa dipisahkan dari pedagogi kritis adalah pemikiran reflektif (reflektive thinking). Menerapkan pedagogi kritis dalam pembelajaran sejarah artinya menekankan teori kritis sebagai alat analisis untuk membaca setiap peristiwa sejarah dalam pembelajaran. Hal ini tentu sangat berkaitan erat dengan kajian pembelajaran sejarah untuk mewujudkan pembelajaran yang bermakna. Diharapkan para peserta didik untuk mampu saling berinteraksi dan aktif untuk mengkaji setiap peristiwa sejarah agar mampu merefleksi diri dan berpikir kritis terhadap peristiwa-peristiwa yang telah terjadi untuk dipetik setiap hikmah dan pelajaran di dalamnya.

Sebagaimana yang disampaikan oleh Sayono (2006) menjelaskan bahwa mata pelajaran sejarah di SMA mengandung dua misi yaitu: Pertama, untuk pendidikan intelektual. Kedua, untuk pendidikan nilai, pendidikan kemanusian, pendidikan pembinaan moralitas, jati diri, nasionalisme, dan identitas bangsa. Senada yang diungkapkan Agung \& Wahyuni (2013) mata pelajaran sejarah adalah mata pelajaran yang memanamkan pengetahuan, sikap, dan nilai mengenai proses perubahan dan perkembangan masyarakat Indonesia dan dunia dari masa lampau hingga masa kini. Susanto (2014) juga mengungkapkan bahwa pembelajaran sejarah hendaklah berorientasi pada pendekatan nilai. Menyampaikan fakta memang sangat penting dalam pembelajaran sejarah, tetapi yang tidak kalah penting adalah bagaimana mengupas fakta-fakta tersebut dan mengambil intisari nilai atau hikmah yang terdapat di dalamnya sehingga peserta didik lebih mawas diri dalam setiap aktivas kehidupan sehari-hari.

Permendiknas No. 22 Tahun 2006, menjelaskan bahwa mata pelajaran sejarah bertujuan agar peserta didik memiliki kemampuan sebagai berikut; a) membangun kesadaran peserta didik tentang pentingnya waktu dan tempat yang merupakan sebuah proses dari masa lampau, masa kini, dan masa depan, b) melatih daya kritis peserta didik untuk memahami fakta sejarah secara 
benar dengan didasarkan pada pendekatan ilmiah dan metodologi keilmuan, c) Menumbuhkan apresiasi dan penghargaan peserta didik terhadap peninggalan sejarah sebagai bukti peradaban bangsa Indonesia di masa lampau, d) Menumbuhkan pemahaman peserta didik terhadap proses terbentuknya bangsa Indonesia melalui sejarah yang panjang dan masih berproses hingga masa kini dan masa yang akan datang, e) Menumbuhkan kesadaran dalam diri peserta didik sebagai bagian dari bangsa Indonesia yang memiliki rasa bangga dan cinta tanah air yang dapat diimplementasikan dalam berbagai bidang kehidupan baik nasional maupun internasional.

Selain itu, pembelajaran sejarah juga berfungsi untuk menyadarkan peserta didik akan adanya proses perubahan dan perkembangan masyarakat dalam dimensi waktu dan untuk membangun perspektif serta kesadaran sejarah dalam menentukan, memahami, dan menjelaskan jati diri bangsa di masa lalu, masa kini, masa depan di tengah-tengah perubahan dunia (Agung \& Wahyuni, 2013). Peserta didik membutuhkan nilai-nilai dan strategi untuk menafsirkan setiap peristiwa sejarah yang pernah terjadi sehingga dapat dikaitkan dengan fenomena di sekitarnya. Maka akan berkembang pula pemikiran kritis dan sikap sosial dari peserta didik tersebut. Peserta didik juga dapat belajar menggunakan keterampilan dan alat-alat studi sosial dalam pembelajaran sejarah, misalnya mencari bukti dengan berpikir ilmiah, keterampilan mempelajari masyarakat, dan sebagainya.

Berdasarkan tujuan dan hakekat pembelajaran sejarah di atas, maka pembelajaran sejarah dapat dikembangkan dengan menggunakan kajian atau pendekatan pedagogi kritis. Pembelajaran sejarah dalam kajian pedagogi kritis merupakan suatu pendekatan yang berupaya membantu peserta didik dalam proses pembelajaran sejarah yang mempertanyakan dan mengkritisi setiap materi dan peristiwa sejarah yang ada sehingga akan melahirkan suatu pemikiran reflektif (reflektive thinking) yang membuat peserta didik mampu belajar dan memaknai setiap peristiwa sejarah dan materi yang ada dalam pembelajaran sejarah di sekolah. Hal tersebut juga sangat relevan dengan pendekatan saintifik yang digunakan dalam kurikulum 2013 untuk pembelajaran sejarah. Dalam kajian pedagogi kritis, bagaimana proses pembelajaran sejarah mampu berupaya membimbing peserta didik untuk dapat menjalani dan memahami kehidupan. Dalam kerangka ini, tujuan yang harus dicapai para anak didik adalah kemampuan untuk dapat menghidupi diri sendiri, kemampuan untuk dapat hidup secara bermakna, dan kemampuan untuk dapat turut memuliakan kehidupan dan orang lain. Hal ini sangat relevan dengan tujuan pembelajaran sejarah yang berupaya membentuk peserta didik agar menjadi warga negara maupun warga dunia yang baik. 


\section{KESIMPULAN}

Konsep dasar pembelajaran sejarah pada hakekatnya merupakan mata pelajaran yang termasuk ke dalam rumpun ilmu-ilmu sosial yang bersumber dari kehidupan sosial masyarakat dan diseleksi dengan menggunakan bantuan teori-teori atau konsep-konsep dari ilmu sosial lainnya. Setiap guru sejarah mestinya paham hakikat keterpaduan dalam mata pelajaran sejarah dengan kajian ilmu sosial. Pembelajaran sejarah juga berupaya untuk menyadarkan peserta didik akan adanya proses perubahan dan perkembangan masyarakat dalam dimensi waktu dan untuk membangun perspektif serta kesadaran sejarah dalam menentukan, memahami, dan menjelaskan jati diri bangsa di masa lalu, masa kini, masa depan di tengah-tengah perubahan dunia.

Dalam pembelajaran sejarah tidak hanya mengajarkan pendidikan kognitif tetapi juga adanya pendidikan nilai yang berasal dari hasil refleksi yang dilakukan atas setiap peristiwa sejarah yang dipelajari. Namun, ternyata masih banyak guru ejarah yang kurang memahami pembelajaran sejarah sebagai mata pelajaran yang penting dalam pembentukan critical thinking dan character building. Masih belum banyak juga yang melakukan pembelajaran sejarah secara bermakna agar peserta didik lebih memahami nilai dan peristiwa sejarah, terutama yang berkaitan dengan fenomena sosial yang ada dalam masyarakat. Bahwasanya dapat dikembangkan dengan menggunakan kajian atau pendekatan pedagogi kritis. Pembelajaran sejarah dalam kajian pedagogi kritis merupakan suatu pendekatan yang berupaya membantu peserta didik dalam proses pembelajaran sejarah yang mempertanyakan dan mengkritisi setiap materi dan peristiwa sejarah yang ada sehingga akan melahirkan suatu pemikiran reflektif (reflektive thinking) yang membuat peserta didik mampu belajar dan memaknai setiap peristiwa sejarah dan materi yang ada dalam pembelajaran sejarah di sekolah. Kajian pedagodi kritis sangat relevan dengan pembelajaran sejarah yang juga berupaya membentuk peserta didik agar menjadi pribadi yang lebih kritis dan berusaha menjadi warga negara yang baik (good citizenship).

Terlepas dari dimensi politik ideologi dan teori yang rumit, implementasi pembelajaran sejarah di kelas dapat mengambil manfaat dari kajian pedagogi kritis ini untuk dapat meningkatkan mutu pendidikan/ pembelajaran dalam membantu peserta didik memiliki kharakter yang baik serta kapabilitas produktif yang tinggi dengan basis nilai yang dapat menjadikan manusia manusiawi. 


\section{DAFTAR PUSTAKA}

Agung, Leo. \& Wahyuni, Sri. (2013). Perencanaan Pembelajaran Sejarah. Yogyakarta: Penerbit Ombak.

Daryanto dan Tatrial. (2012). Konsep Pembelajaran Kreatif. Yoyakarta: Penerbit Gava Media.

Hidayat, Rahmat. (2013). Pedagogi Kritis: Sejarah, perkembangan dan $\quad$ pemikiran. Depok: PT Rajagrafindo Persada.

MacDonald, Doune. (2002). Critical Pedagogy: What It Might Look Like and Why does It Matter?. Dalam Laker, Anthony (ed). The Sociology of Sport and Physical Education: An Introductory Reader. London: Routledge Falmer

Permendiknas Nomor 22 Tahun 2006 tentang Standar Isi

Pernantah, Piki Setri. (2016). Internalisasi Nilai-Nilai Multikultural dalam Pembelajaran Sejarah di Sekolah. Prosiding Seminar Nasional Program Studi Sejarah Se- Indonesia～(p.). Yogyakarta: Universitas Negeri Yogyakarta.

Sadulloh, Uyoh, dkk. (2011). Pedagogik. Bandung: Alfabeta.

Sayono. (2013). Pembelajaran Sejarah di Sekolah: Dari Pragmatis Ke Idealis. Jurnal SEJARAH DAN BUDAYA, Tahun Ketujuh, Nomor 1, Juni 2013

Susanto, H. (2014). Seputar Pembelajaran Sejarah: Isu, Gagasan, dan Strategi Pembelajaran. Yogyakarta: Aswaja Pressindo 